\title{
LUNAR HABITAT AIRLOCK/SUITLOCK
}

Brand Norman Griffin ${ }^{1}$ A.M., ASCE

\begin{abstract}
Airlocks for lunar Extravehicular Activity (EVA) will be significantly different than previous designs. Until now, airlocks operated infrequently and only in the "clean" weightless environment, but lunar airlocks are planned to be used much more often (every other day) in a dusty, gravity environment. Concepts for airlocks were analyzed by the NASA, JSC Habitability Focus Element during recent lunar outpost studies. Three airlock types were identified; an Airlock (AL) or independent pressure vessel with one hatch to the outside and the other to the Habitat. A Suitlock (SL) which shares a pressure bulkhead with the Habitat allowing rear-entry suits to remain on the dusty side while the crew enters/exits the Habitat. The third option is the Suitport (SP) which offers direct access from the habitable volume into an externally mounted suit. The SP concept was not compared, however between the AL and SL, the AL was favored.
\end{abstract}

\section{Introduction}

Most people are surprised that EVA for all the 6 lunar landings was done without an airlock. In fact, it wasn't until after the Apollo Program, during Skylab, that Americans included their first airlock on a spacecraft. The early programs could not accommodate the additional weight, power and volume required for airlocks. Since then, the Shuttle and International Space Station have included airlocks that are designed for EVA in a clean, weightless environment. Weightless hatches are round, but hatches in the gravity environment must accommodate a walking astronaut looking more like submarine hatches. Furthermore, the experience from Apollo exposed the hazards of bringing the abrasive lunar dust into the pressurized volume. It affects crew health, spacecraft cleanliness along with the operation of pumps, filters, seals, and hinges.

For this study, the term, airlock represents the inclusive class of pressure vessels used for moving EVA crew and cargo between the lunar surface and the habitable volume. The acronyms AL and SL depict different airlock concepts.

\section{Objectives}

The following objectives were established to create common ground for comparison: 1. Minimize loss of resources (air), 2. Design for simple and safe operations, 3. Stress commonality (e.g., with ascent/descent vehicle and pressurized rover), 4. Minimize overall program mass, 5. Minimize the intrusion of lunar dust, and 6 . Accommodate the transfer of crew, cargo and an incapacitated crew member.

\footnotetext{
${ }^{1}$ Gray Research, Inc. 655 Discovery Drive, Huntsville, AL 35806; PH (256) 319 8260; email: bgriffin@gray-research.com
} 


\section{Description of AL and SL}

The difference between the AL and SL is that ALs are separate pressure vessels and SLs are structurally integral with the Habitat sharing a common pressure bulkhead. This feature allows different means of entry/exit for the EVA crew. For the AL, the crew walks through a hatchway and for the SL they back up to a bulkhead interface then using a rear-entry suit, exit directly into the Habitat. Features of the two concepts are described in Fig. 1.

\begin{tabular}{|c|c|c|}
\hline FEATURE & AL & SL \\
\hline Layout & $\begin{array}{l}\text { Separate vertical cylinder, elliptical end } \\
\text { domes, opposing hatches }\end{array}$ & $\begin{array}{l}\text { Integrated vertical cylinder, elliptical end } \\
\text { domes, entry hatch, } 2 \text { backpack hatches and } \\
\text { an equipment hatch }\end{array}$ \\
\hline $\begin{array}{l}\text { Hatches and } \\
\text { Seals }\end{array}$ & $\begin{array}{l}\text { One submarine hatch (other hatch part of } \\
\text { Hab) } 9.3 \mathrm{~m} \text { ( } 366 \mathrm{in}) \text { of seal, } 18.6 \mathrm{~m} \text { ( } 732 \mathrm{in}) \\
\text { for } 2 \text { airlocks }\end{array}$ & $\begin{array}{l}\text { One submarine hatch, two suitlocks and one } \\
\text { equipment hatch } 13.7 \mathrm{~m}(541 \mathrm{in}) \text { of seal, } 27.4 \\
\mathrm{~m}(1082 \text { in) for } 2 \text { suitports }\end{array}$ \\
\hline Weight & Assume $510 \mathrm{~kg}$ & $\begin{array}{l}\text { Assume } 593 \mathrm{~kg} \text { ( } 25 \mathrm{~kg} \text { for ea. suitport hatch } \\
\text { accommodation, STS airlock hatch } 32.7 \mathrm{~kg} \text { ) }\end{array}$ \\
\hline Volume & $4.25 \mathrm{~m}^{3}\left(150 \mathrm{ft}^{3}\right)$ & $4.25 \mathrm{~m}^{3}\left(150 \mathrm{ft}^{3}\right)$ \\
\hline Pumping & $0.133 \mathrm{Kwhr}$ (ISS), 30 minutes & $0.133 \mathrm{Kwhr}$ (ISS), 30 minutes \\
\hline EVA aids & Hand holds & $\begin{array}{l}\text { Hand holds, PLSS docking guides, height } \\
\text { adjustment }\end{array}$ \\
\hline Dust Control & $\begin{array}{l}\text {-Suit is brought into Hab volume } \\
\text { •Equipment brought into Hab volume }\end{array}$ & $\begin{array}{l}\text {-Suit remains in the airlock except for repair } \\
\text { and servicing } \\
\text { •Equipment brought into Hab volume }\end{array}$ \\
\hline
\end{tabular}

\section{Lunar EVA Anthropometrics}

Figure $1 A L$ and SL Features

At this time, there is no official lunar EVA suit, but it is not necessary to have actual suit dimensions to compare airlock options. Space suits tend to conform to the
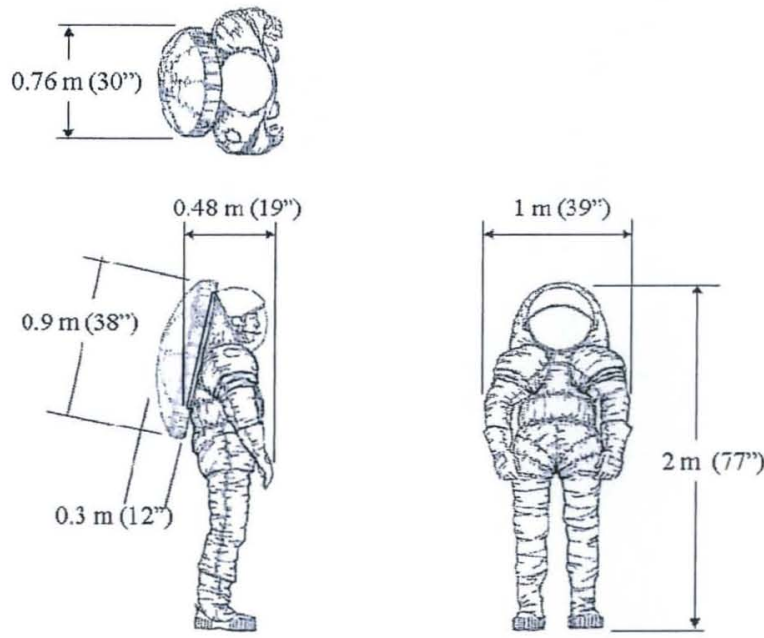

Figure 2 Lunar EVA Anthropometry size of the crew member with an added Portable Life Support System (PLSS) on their back. This means that the anthropometry of the astronaut population can be "suitfactored" for approximate dimensions. Low lunar gravity will also influence suit sizing. Weightless crew members experience as much as 2 inches growth along their vertebral column. Assuming a similar, but less severe reaction, lunar suit height was increased by 1 inch to accommodate for the1/6g gravity. Fig. 2 shows the assumed lunar anthropometry. 
A single representative suit was selected for operations and sizing. The only suit to walk on the Moon, the Apollo lunar suit, was not an option because it did not have a rear-entry and there have been significant advances in suit design since then.
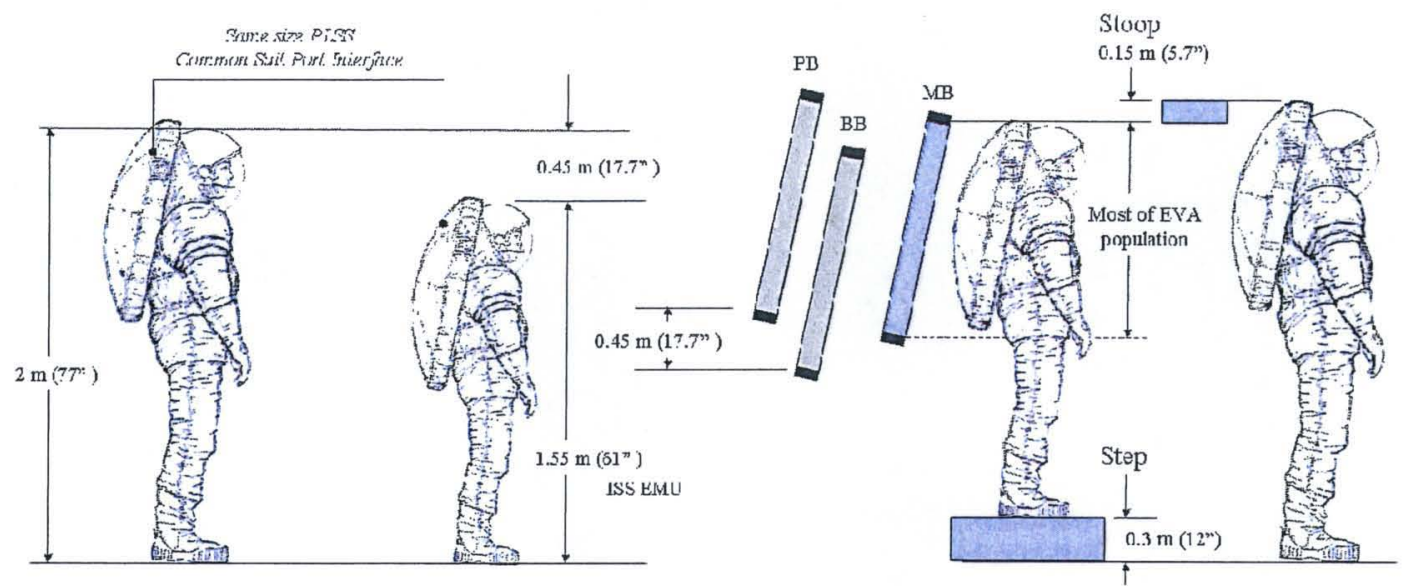

Figure 3 Lunar Suit Range

Figure 4 Common Height Rear-Entry Interface

However, a suit called Mark III has a rear entry and is currently being used in simulated planetary field tests. Therefore, it was selected the representative suit and scaled to fit the EVA population.

Both options must be designed for the entire population range, but the SL must also accommodate a $.45 \mathrm{~m}$ (17.7 in.) height differential (See Fig. 3) for mating the PLSS to the bulkhead. A simple Step or Stoop solution provides a common height interface where the shorter crew would use a step and the taller ones would

$\mathrm{AL}$

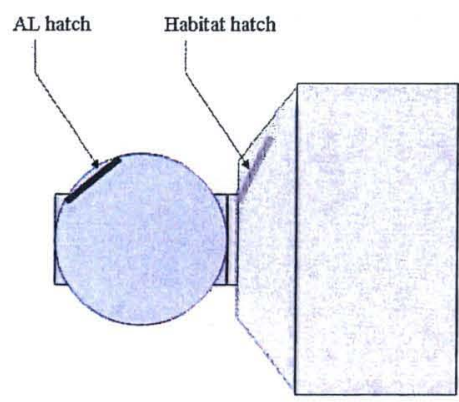

One hatch on AI Can be delivered as separate unpressurized element
SL

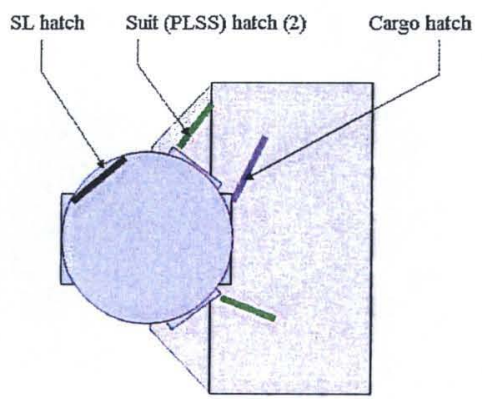

Four hatches on SL Integrated wilh Habitat

Figure 5 Hatches for $A L$ and $S L$ have to stoop. The step height shown in Fig. 4 favors the median population rather than extreme crew members. Furthermore, owing to pressure suit mobility, stepping is favored over stooping.

Type and Number of Hatchways

The airlock hatchways are structural openings designed for EVA crew and cargo to pass between the lunar surface and the Habitat. See Fig. 5. In addition to normal operations, they are also required to accommodate an incapacitated crew member. For hatches, the principal difference between ALs and SLs is that the SL has hatchways for rear-entry suits whereas the AL does not. This means that the AL uses one type of hatch for all functions as compared with 3 types for the SL. As a result, the AL requires only one hatch because the Habitat provides the other, while the SL requires four. 


\section{Operable Seal Length}

As the name implies, airlocks are supposed to retain and not leak air. The seals in operable hatch represent the greatest potential leak path which is why the
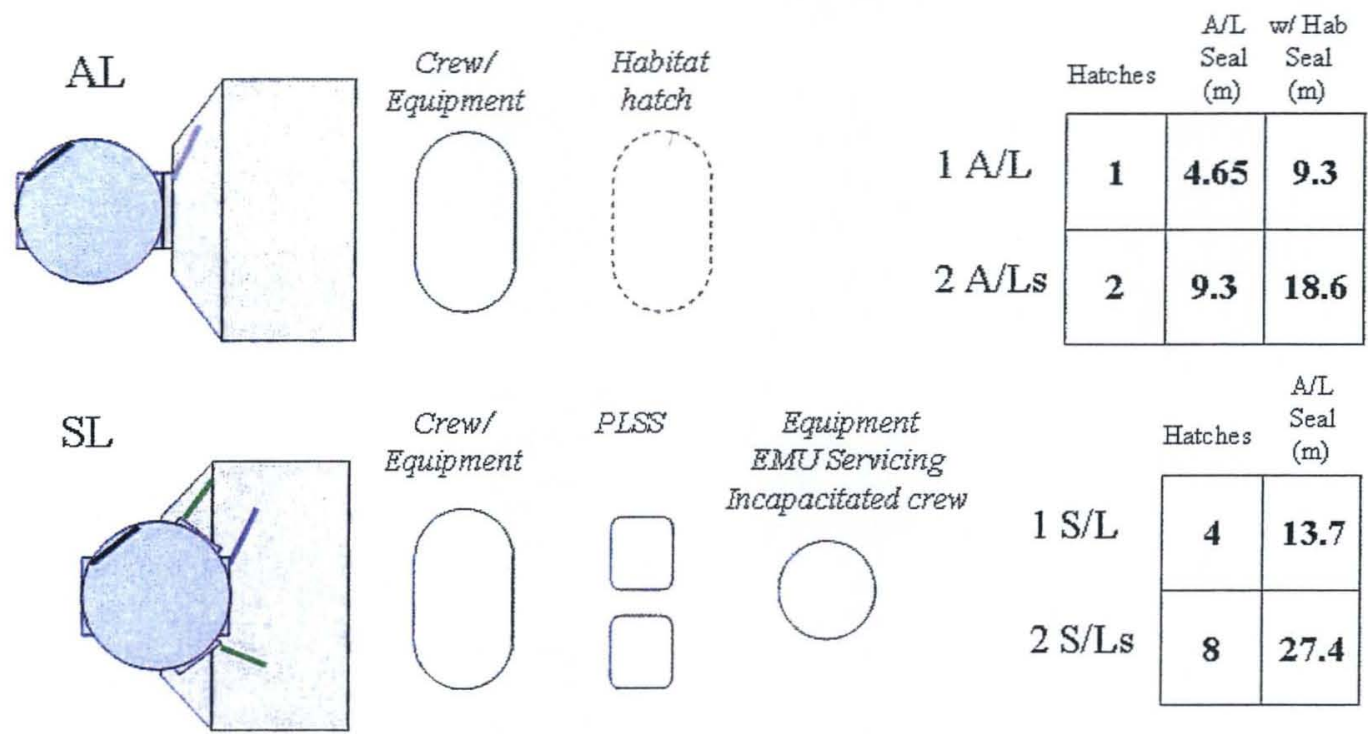

Figure 6 Comparison of Hatch Seal Length

seal length was used as a metric comparing leak risk. Counter pressure hatches have been used in spacecraft but they add complexity and weight. Therefore, pressure assisted hatches are used in both concepts. The exception is the suit hatch in the SL which requires a special mechanism to seal the suit against the bulkhead. This

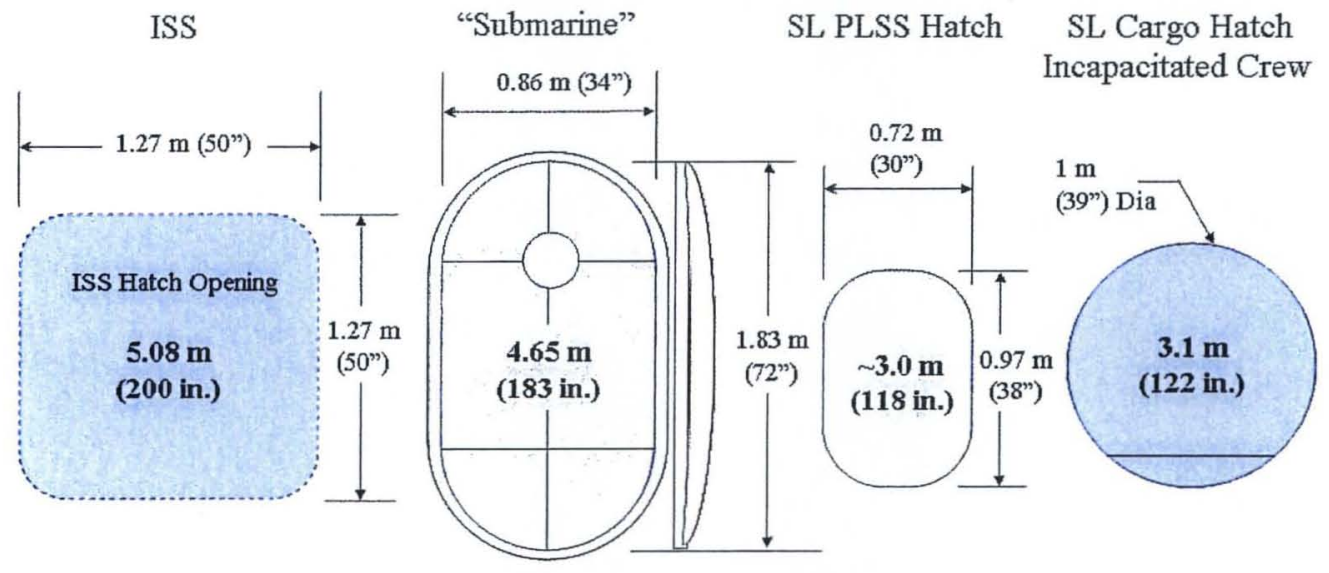

Figure 7 Representative Hatch Geometries

connection will be challenging because the EVA crews in "dirty" suits have to make a secure pressure seal inside a "dirty" SL. Even more significant is the likelihood of seal damage, surface scratching and particulate interference from the abrasive lunar dust. Furthermore, the high frequency of EVA exposes the suit, airlock interior and seals to increasing levels of contamination.

There are two seals for the PLSS, one for the suit-to-bulkhead and the other for the interior hatch cover. Because the hatch cover will be the primary seal, only the length of one PLSS seal was used in this comparison. Even so, the results show the SL has $4.4 \mathrm{~m}$ (47\%) more seal length than the AL when including the Habitat 
hatch. See Fig 6. Excluding the Habitat hatchway, the SL has $8.05 \mathrm{~m}$ (173\%) more seal length. These percentages are derived from representative hatch sizes (Fig. 7) but findings should remain consistent based on the SL having four hatches and the AL one.

\section{Airlock Sizing (Number of Crew at One Time)}

\begin{tabular}{|c|c|c|c|c|c|c|}
\hline & $\begin{array}{l}\text { Lander } \\
\text { w/Airlock }\end{array}$ & $\begin{array}{c}\text { Lander } \\
\text { w/o Airlock }\end{array}$ & $\begin{array}{l}\text { Habitat } \\
\text { w/ } 1 \text { Airlock }\end{array}$ & $\begin{array}{l}\text { Habitat } \\
\text { w/ } 2 \text { Airlocks }\end{array}$ & $\begin{array}{l}\text { Pressurized } \\
\text { Rover } \\
\text { w/ Airlock }\end{array}$ & $\begin{array}{l}\text { Pressurized } \\
\text { Rover } \\
\text { w/o Airlock }\end{array}$ \\
\hline $\begin{array}{l}\text { Two Crew } \\
\text { Airlock }\end{array}$ & $\begin{array}{l}1 \text { airlock per } \\
\text { landing } \\
\text { (cycle } 2 \text { crew } \\
\text { in and out) }\end{array}$ & $\begin{array}{c}\text { Reasonable } \\
\text { option (like } \\
\text { Apollo) }\end{array}$ & $\begin{array}{c}\text { Cabin depress } \\
\text { for } \\
\text { emergency } \\
\text { ingress/egress }\end{array}$ & $\begin{array}{c}\text { Reasonable } \\
\text { option }\end{array}$ & $\begin{array}{c}\text { Reasonable } \\
\text { option }\end{array}$ & $\begin{array}{c}\text { Reasonable } \\
\text { option (like } \\
\text { Apollo) }\end{array}$ \\
\hline $\begin{array}{l}\text { Four Crew } \\
\text { Airlock }\end{array}$ & $\begin{array}{c}2 \text { or } 4 \text { crew at } \\
\text { once } \\
\text { Questionable } \\
\text { option }\end{array}$ & $\begin{array}{c}\text { Reasonable } \\
\text { option (like } \\
\text { Apollo) }\end{array}$ & $\begin{array}{l}\text { Cabin depress } \\
\text { for } \\
\text { emergency } \\
\text { ingress/egress }\end{array}$ & $\begin{array}{c}\text { Excessive } \\
\text { capability } \\
\text { Questionable } \\
\text { option }\end{array}$ & $\begin{array}{l}\text { Two crew per } \\
\text { rover (Not an } \\
\text { option) }\end{array}$ & $\begin{array}{l}\text { Two crew per } \\
\text { rover (Not an } \\
\text { option) }\end{array}$ \\
\hline $\begin{array}{l}\text { Two Crew } \\
\text { Suitlock }\end{array}$ & $\begin{array}{l}1 \text { suitlock per } \\
\text { landing } \\
\text { (cycle } 2 \text { crew } \\
\text { in and out) }\end{array}$ & $\begin{array}{l}\text { Reasonable } \\
\text { option (like } \\
\text { Apollo) }\end{array}$ & $\begin{array}{c}\text { Cabin depress } \\
\text { for } \\
\text { emergency } \\
\text { ingress/egress }\end{array}$ & $\begin{array}{c}\text { Reasonable } \\
\text { option }\end{array}$ & $\begin{array}{c}\text { Reasonable } \\
\text { option }\end{array}$ & $\begin{array}{l}\text { Reasonable } \\
\text { option (like } \\
\text { Apollo) }\end{array}$ \\
\hline
\end{tabular}

Figure 8 Airlock Opportunities For Habitable Elements

Because EVA uses the buddy-system, airlocks should accommodate at least 2 crew members at once. In addition to the Habitat, the ascent/descent vehicle and pressurized rover are candidates for airlocks. See Fig 8. The Habitat and

\begin{tabular}{|c|c|c|c|}
\hline$A / L *(k g)$ & 510 & & \\
\hline $\mathrm{S} / \mathrm{L} *(\mathrm{~kg})$ & 594 & & \\
\hline Option & Mass & Total w pumps.s & Notes \\
\hline $1 \mathrm{~A} / \mathrm{L}$ for $\mathrm{Hab}$ & 510 & 631.1 & $\begin{array}{l}\text { Depress Hab element for emerg. } \\
\text { Ingress/egress }\end{array}$ \\
\hline $2 \mathrm{~A} / \mathrm{L}$ for $\mathrm{Hab}$ & 1020 & 1262.2 & \\
\hline $1 \mathrm{~S} / \mathrm{L}$ for $\mathrm{Hab}$ & 594 & 715.1 & $\begin{array}{l}\text { Depress Hab element for emerg. } \\
\text { Ingress/egress }\end{array}$ \\
\hline $2 \mathrm{~S} / \mathrm{L}$ for $\mathrm{Hab}$ & 1188 & 1430.2 & \\
\hline $1 \mathrm{~A} / \mathrm{L}$ for $\mathrm{Hab}+\mathrm{Lander} \mathrm{AL}$ & 3570 & 4417.7 & Assumes 6 crew landers \\
\hline $2 \mathrm{~A} / \mathrm{L}$ for $\mathrm{Hab}+\mathrm{Lander} \mathrm{AL}$ & 4080 & 5048.8 & Assumes 6 crew landers \\
\hline $1 \mathrm{~S} / \mathrm{L}$ for $\mathrm{Hab}+\mathrm{Lander} \mathrm{S} / \mathrm{L}$ & 4158 & 5005.7 & Assumes 6 crew landers \\
\hline $2 \mathrm{~S} / \mathrm{L}$ for $\mathrm{Hab}+\mathrm{Lander} \mathrm{S} / \mathrm{L}$ & 4752 & 5720.8 & Assumes $6 \mathrm{crew}$ landers \\
\hline $1 \mathrm{~A} / \mathrm{L}$ for $\mathrm{Hab}+\mathrm{Lander} \mathrm{A} / \mathrm{L}+\mathrm{P}$ Rover $\mathrm{AL}$ & 4080 & 4927.7 & Assumes 6 crew landers \\
\hline $2 \mathrm{~A} / \mathrm{L}$ for $\mathrm{Hab}+\mathrm{Lander} \mathrm{A} L \mathrm{~L}+\mathrm{P}$ Rover $\mathrm{A} / \mathrm{L}$ & 5100 & 6068.8 & Assumes $6 \mathrm{crew}$ landers \\
\hline $1 \mathrm{~S} / \mathrm{L}$ for $\mathrm{Hab}+\mathrm{Lander} S / \mathrm{L}+\mathrm{P}$ Rover $\mathrm{S} / \mathrm{L}$ & 4752 & 5599.7 & Assumes 6 crew landers \\
\hline 2 S/L for Hab + Lander S/L + P Rover S/L & 5346 & 6314.8 & Assumes 6 crew landers \\
\hline ISS Pumpi** & 79.4 & \multicolumn{2}{|c|}{ *Extrapolation from ISS crew lock, JSC20466 Rev B } \\
\hline Equalization valve*** & 6.9 & \multicolumn{2}{|c|}{ ** Space Station Freectom Airlock Depress/Repress System } \\
\hline Controls** & 14.8 & \multicolumn{2}{|c|}{ Design and Performance, SAE 921378 , D. James, July 13-16, 1992} \\
\hline Tarks*:*** & 20 & \multicolumn{2}{|l|}{ ****Estimate } \\
\hline
\end{tabular}

Figure 9 Mass for AL and SL

ascent/descent vehicle are designed for 4 crew while the pressurized rover accommodates 2. This means the choices are either an airlock for 4 (all at once) or 2 (cycled twice). By increasing the diameter, ALs can easily accommodate 4 however; 
SLs are geometrically challenged because they have to provide 4 rear-entry hatches lined up shoulder to shoulder. The Mark III PLSS is $0.76 \mathrm{~m}$ (30 in.) wide. Allowing $0.03 \mathrm{~m}$ ( $3 \mathrm{in}$.) on either side for bulkhead structure and arm movement, it takes $3.7 \mathrm{~m}$ (144 in.) for 4 crew. With an added hatch for incapacitated crew, this is excessive.

Smaller airlocks are attractive for several reasons. They weigh less, package better and have less air to pump. It is assumed that each cycle of the airlock loses $10 \%$ of its air. Thus the incentive is to make an airlock as small as possible while still allowing for inward hatch swing and some crew movement. Consequently, both the $\mathrm{AL}$ and SL were sized for 2 crew members.

\section{Crew and Cargo Translation}

The translation of crew and cargo through the AL and SL is shown in Fig, 10 and the following discussion provides an expanded description for each option.
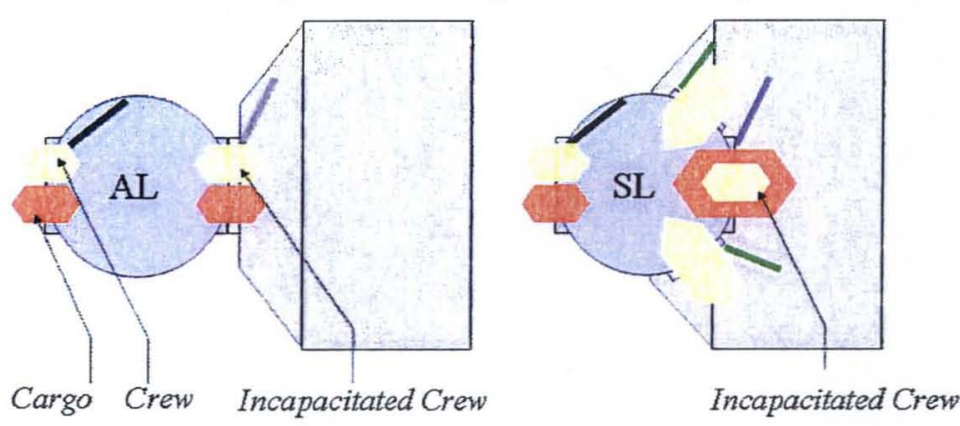

Figure 10 Crew and Cargo Translation

\section{Airlock (AL)}

Two EVA crew members step through an open hatch into the $\mathrm{AL}$ chamber. The hatch is closed and the chamber pressurized. Then, the hatch to the Habitat is opened and depending on suit design, the crew

begin doffing while in the airlock or in the Habitat.

For egress from the Habitat, the suit inspection, preparation and pre-breathe can take place either in the Habitat or AL. After checkout, the Habitat hatch is

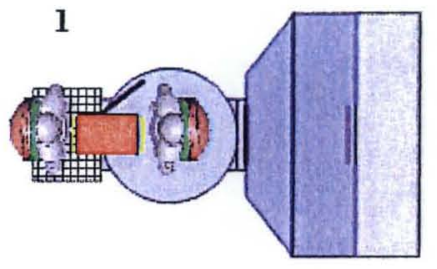

Crew moves equipment through hatch

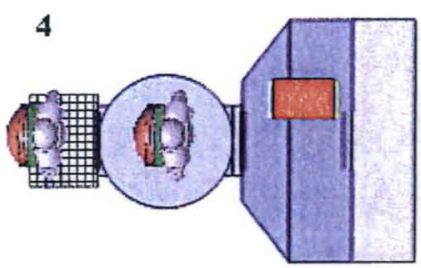
Pump down A/L (ISS 30 min.) EVA crewmember may remain in $\mathrm{Hab}$

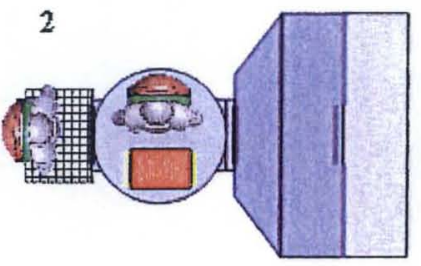

Seal and pressurize $A / L$

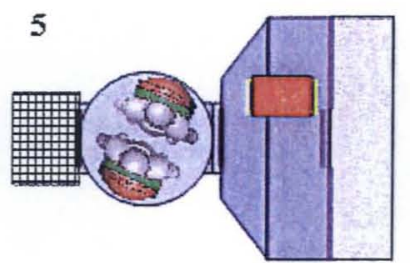

Pressurize $A / L$

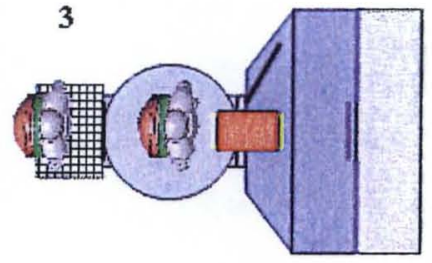

Pass equipment into $\mathrm{Hab}$

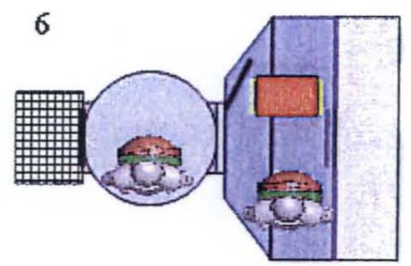

Stow suits

Figure 11 Process for Moving Cargo through $A L$ closed, the airlock pumped down, pressure equalized and the crew opens the outer hatch to the lunar surface. 
Transporting an incapacitated EVA crew member through the AL in lunar gravity is easier than the same operation on Earth. Assume the incapacitated crew member is unconscious and the suit is still functioning at the normal pressure. The pressure will tend to shape the suit similar to an out-stretched person except for low torque joints which are free to move. A new lunar suit with a crew member inside may weigh $186 \mathrm{~kg}(409 \mathrm{lb})$ which translates to $31 \mathrm{~kg}(68 \mathrm{lb})$ on the Moon. No doubt this is a heavy load, but manageable for short distances in an emergency. The incapacitated crew member is "positioned" inside the airlock allowing the hatch to swing closed while the mobile crew member occupies the remaining volume. Once the chamber is pressurized and the inner hatch opened, an inside crew member will assist transporting the incapacitated crew member. AL hatches do not need to be resized because both hatches are large enough to accommodate all operations.

There are two ways to move cargo through the AL. The first is for large cargo that leaves no room for the EVA crew. This hardware is placed in the chamber, pressurized, transferred out of the AL by the inside crew, then, resealed, pumped down and used by the waiting EVA crew. During the cycle time, it is envisioned that the crew connect life-support umbilicals to the outside of the AL rather than consume limited PLSS resources. For the second method, one or both of the EVA crew carry the cargo with them into the AL. See Figure 11.

\section{Suitlock (SL)}

Moving from the lunar surface into the Habitat using the SL begins like the AL, however, the procedure differs once inside the chamber. See Fig. 12. Each crew

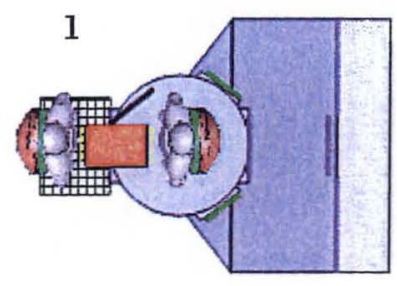

Crew moves equipment through hatch

4

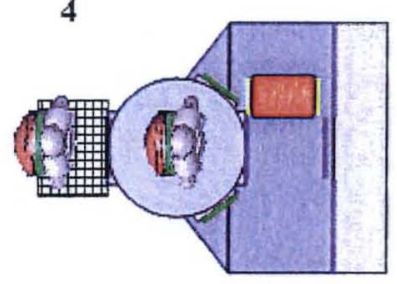

Pump down S/L (ISS 30 min.)

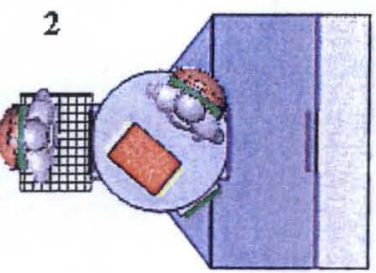

Seal and pressurize $S / L$

5

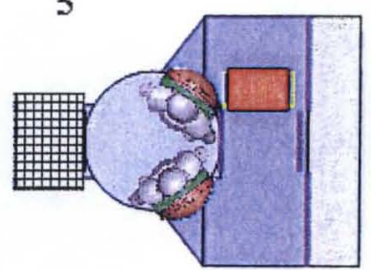

Pressurize S/L

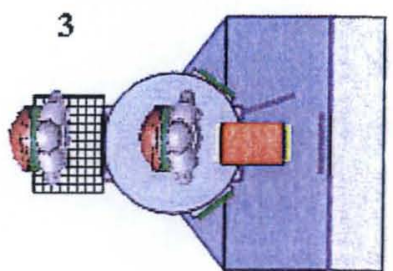

Pass equipment into $\mathrm{Hab}$

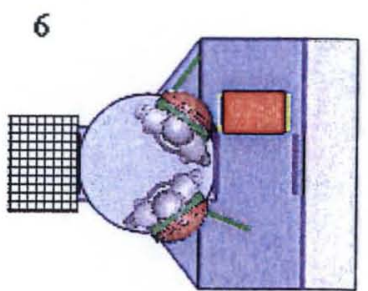

Stow suits

EVA crewmember may remain in $\mathrm{Hab}$

Figure 12 Process for Moving Cargo through SL

member backs the suit into a rear-entry interface making sure that the seal is secure. Then, either an EVA or inside crew member opens the pressure hatch that encloses the PLSS. After this, the PLSS is opened allowing the crew member in the suit to back out into the Habitat. 
Egress from the SL first requires the crew to enter the dustibule for inspection of the suit, helmet, gloves and boots. After this, the hatch is sealed and the crew conducts a pre-breathe, seals the PLSS hatch then closes the outer PLSS cover hatch. Completing checkout, pump down and pressure equalization, the crew disconnects the suit from the PLSS interface and exits the SL.

Like the AL, an incapacitated crew member is positioned in the dustibule of the SL then the outer hatch door closed. Because the incapacitated crew member will not be able to connect with the PLSS interface nor exit the suit, a separate hatchway is used. In these circumstances, the dustibule of the SL is pressurized allowing the Habitat hatch to be opened and the incapacitated crew member brought inside. The mobile EVA crew member has the option of using the PLSS interface to exit the suit.

For cargo transfer, large items are transferred through the inner hatch which is the same hatch used for the incapacitated crew member. Another difference is because the EVA crew uses the rear-entry hatch, smaller equipment must stay in the SL dustibule until the EVA crew has exited their suits and the chamber pressurized allowing access from the inside to retrieve the hardware.

\section{Dust Control}

For both AL and SL, the crew removes most loose dust before entering. See Fig. 13. A secondary level of dust control occurs in the dustibule. The crew in the SL exits the suit directly into the Habitat while AL suits enter into a controlled area in
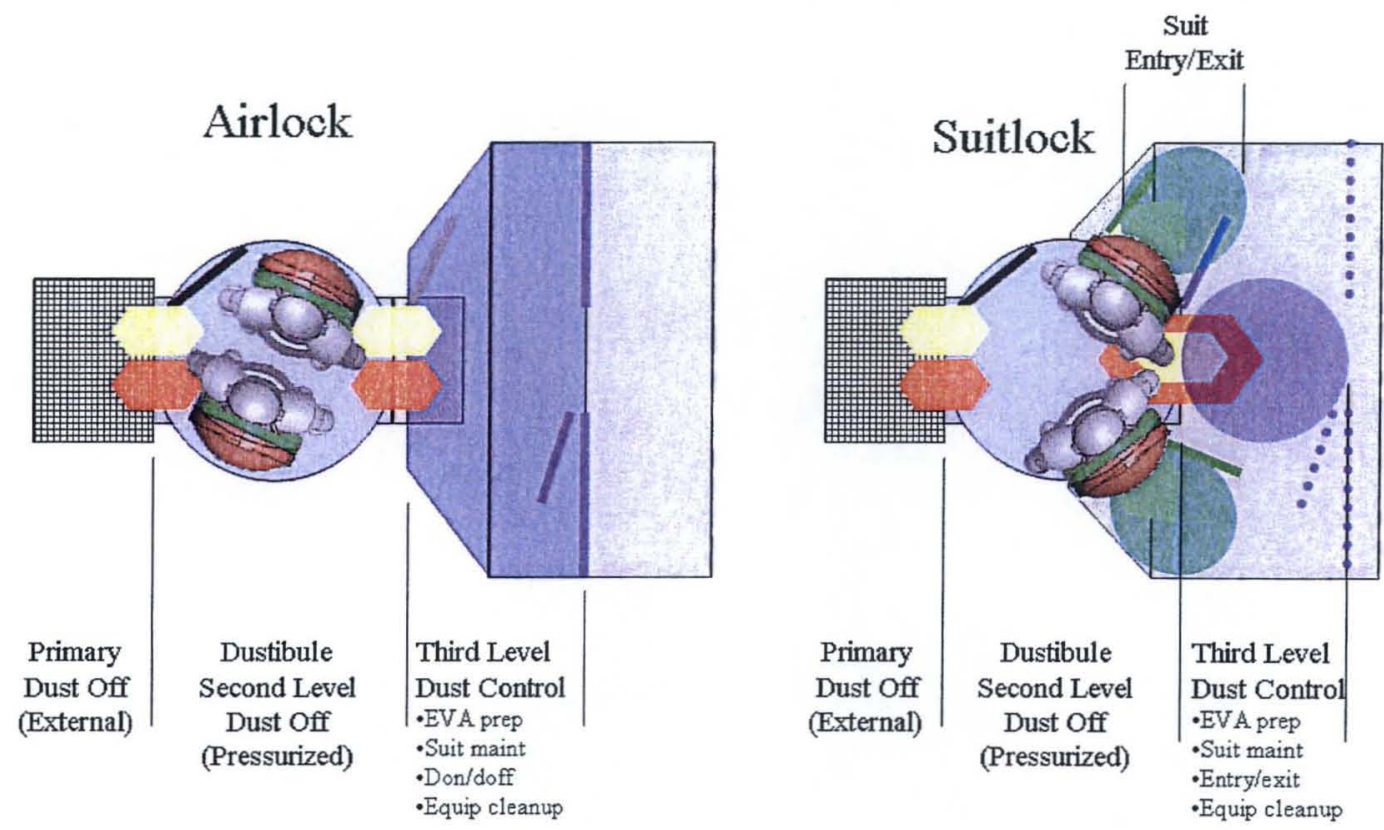

Figure 13 AL and SL Dust Control

the Habitat. It is important to note that although the suits are isolated, it will be necessary for the EVA crew to enter the dusty area prior to each EVA to "pre-flight" the suit. Furthermore, for both the AL and SL, dusty suits will need to be brought into the Habitat for scheduled and unscheduled maintenance.

\section{Suit Stowage (Don/Doff)}

The AL can accommodate any suit type, but the SL requires a pressure tight interface with a rear-entry suit. The SL is designed for suits to remain in the 
dustibule. Like the Shuttle airlock, suits can also be stowed in the AL, but this is optional. It is important to note that with 4 crew members and one AL or SL, two suits are stowed in the Habitat. This means that with either concept, there will always be two "dirty" suits in the Habitat. See Fig. 14

$\mathrm{AL}$
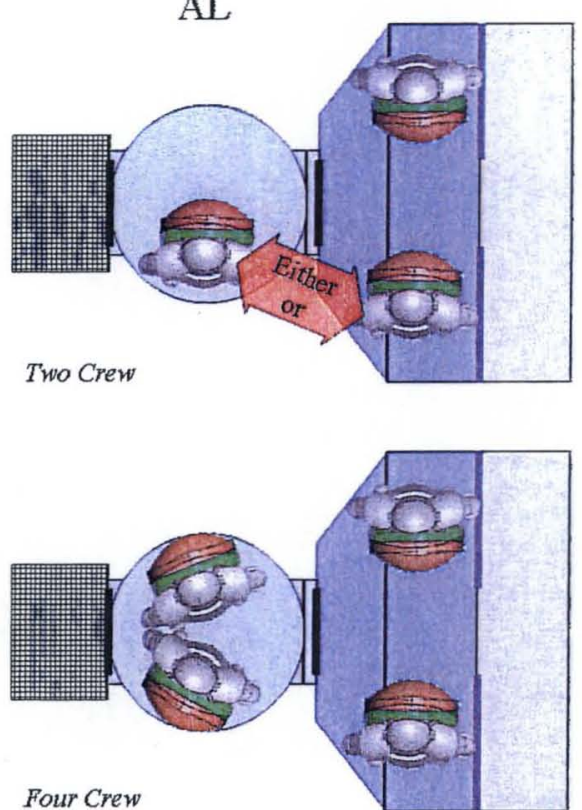

SL
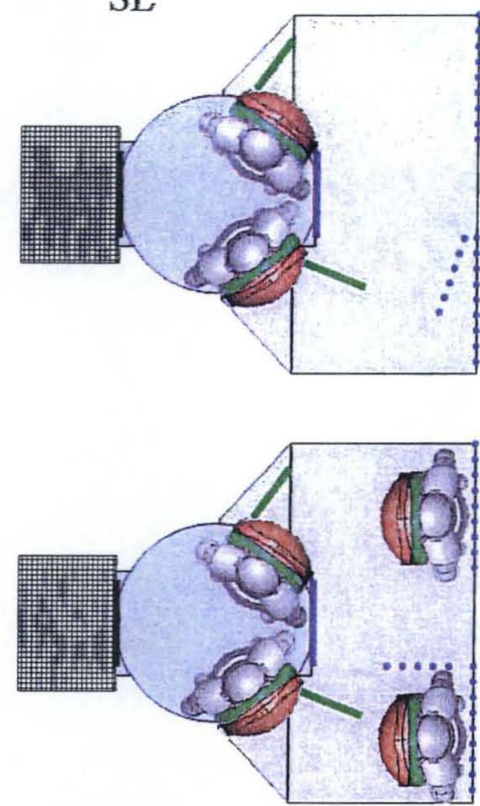

Figure 14 AL and SL Suit Stowage

Donning and doffing the suit is closely tied to stowage. For the SL, the crew

\begin{tabular}{|c|c|c|}
\hline $\begin{array}{c}\text { Suit } \\
\text { Configuration }\end{array}$ & $\begin{array}{l}\text { Don/Doff } \\
\text { Technique }\end{array}$ & $\begin{array}{l}\text { Donning } \\
\text { Volume }\end{array}$ \\
\hline $\begin{array}{l}\text { Apollo A7LB } \\
\text { (lunar EMU) }\end{array}$ & \begin{tabular}{|l} 
Dual-Plane \\
Zipper
\end{tabular} & $5.47 \mathrm{~m}^{3}\left(193 \mathrm{ft}^{3}\right)$ \\
\hline Shuttle SSA & \begin{tabular}{|l|} 
Single-Plane \\
Horizontal Body \\
Seal Closure \\
\end{tabular} & $3.64 \mathrm{~m}^{3}\left(129 \mathrm{ft}^{3}\right)$ \\
\hline Shuttle LES & $\begin{array}{l}\text { Single-Plane } \\
\text { Zipper }\end{array}$ & $2.63 \mathrm{~m}^{3}\left(93 \mathrm{ft}^{3}\right)$ \\
\hline MKIII"* & $\begin{array}{l}\text { Single-Plane } \\
\text { Rear Entry }\end{array}$ & $\begin{array}{l}3.23 \mathrm{~m}^{3}\left(114 \mathrm{ft}^{3}\right) \\
4.78 \mathrm{~m}^{3}\left(\mathrm{ft}^{3}\right) * * * * *\end{array}$ \\
\hline
\end{tabular}

*JSC 26019 Space Suit Donning Volumetric Evaluations, Aug 28, 1992

*k:k Most representative of lunar suit

*:**:CEV Internal Volume Study Report, NASA, JSC 10-21-05

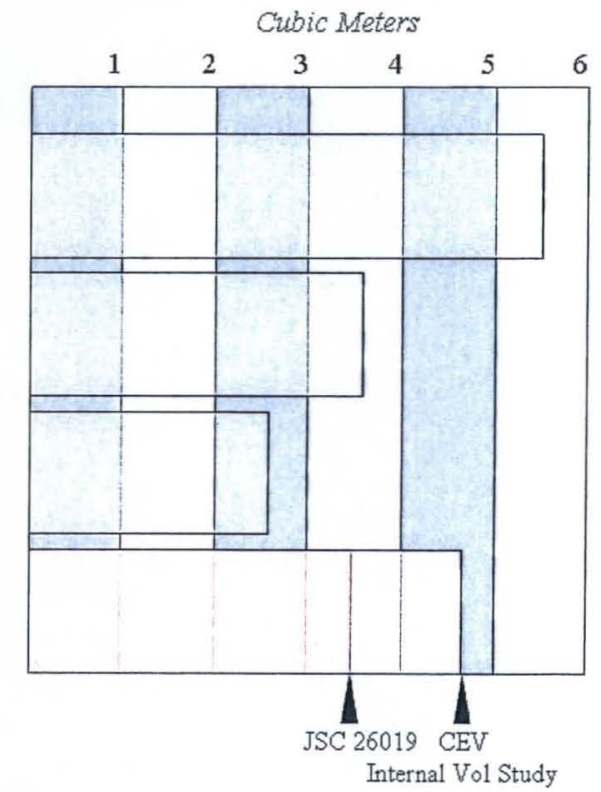

Figure 15 Donning Volume for Space Suits

will enter and exit through the PLSS opening. For the AL, an EVA anteroom is the most reasonable location for donning and doffing suits. An estimated volume for this activity is shown in Fig. 15. The rear-entry for the SL requires room above the 
helmet and the proper angle to drive the legs into the suit. These dimensions were derived from lunar gravity testing on NASA's KC-135 shown in Fig. 16.
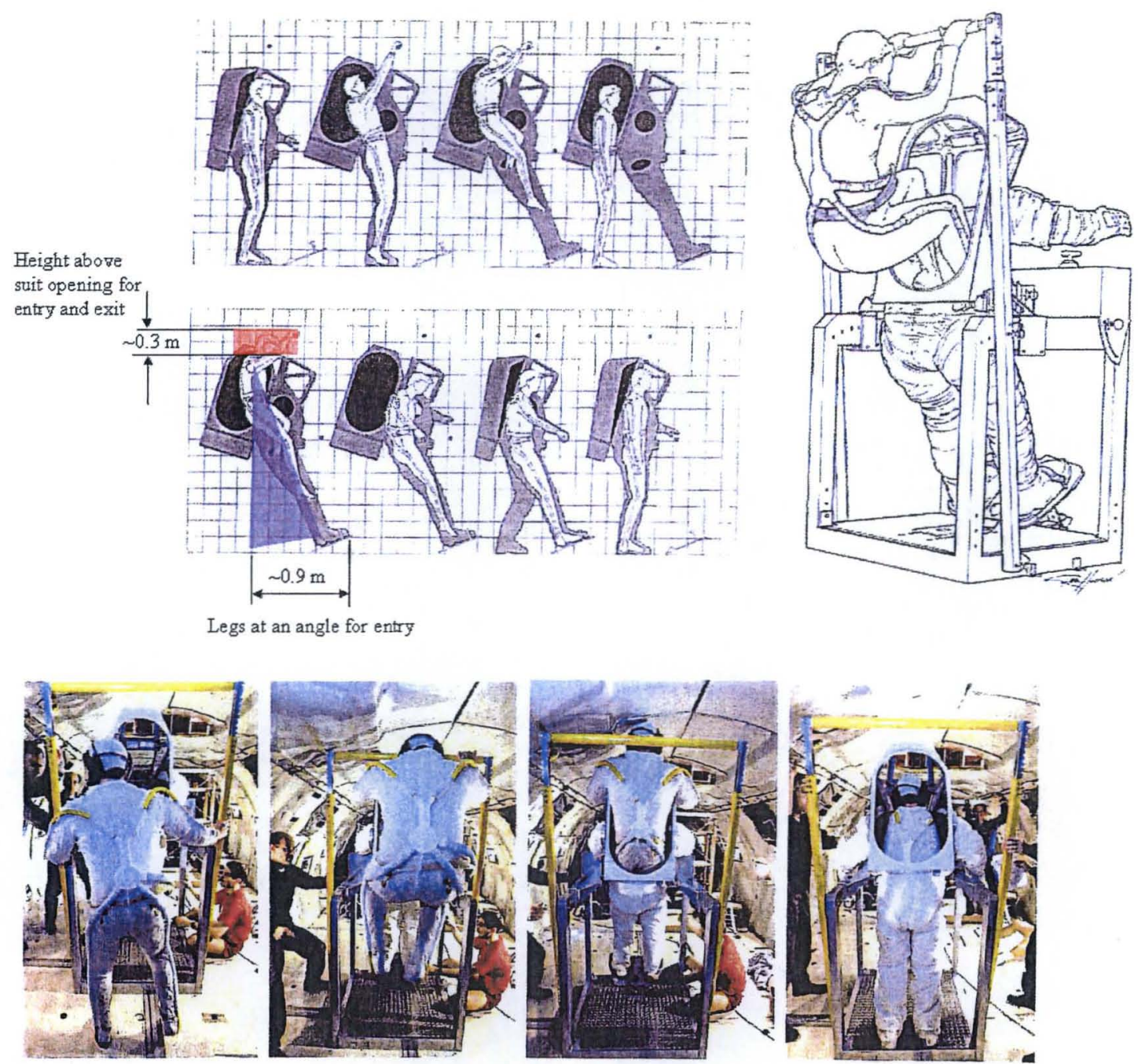

Figure 16 Rear-entry Suit Testing in Lunar Gravity

\section{Suit Inspection Servicing and Repair}

Because of the environment, type of work and frequency, suits will require a thorough inspection prior to EVA. Lunar dust will easily wear away outer layers, scratch surfaces and degrade thermal properties. Therefore, the readiness of gloves, boots, visors, cameras, lights, displays and thermal coatings will need to be verified for safe and productive excursions.

\section{Separate vs. Integrated Airlock}

Unlike the SL, the AL is considered an independent system. That is, it can be delivered, connected and removed separately from the Habitat. The SL shares a common structural bulkhead and is therefore integral with the Habitat. The advantages of an independent AL system are: 1. Flexibility in delivery (lander) manifesting, 2. Relocatable (e.g., move from ascent vehicle to Habitat), 3. Separate design, development, fabrication, test, and checkout, 4. Separate procurement. 5. Replaceable (because of wear, damage or upgrade), 6. Optimized geometry (not tied 
to Habitat dimensions), and 7. Commonality with ascent/descent vehicle (able to be jettisoned for descent abort).

\section{AL/SL Configurations}

Other configurations are possible, but most fall into 2 types. These are either a full diameter or a vertical cylinder.

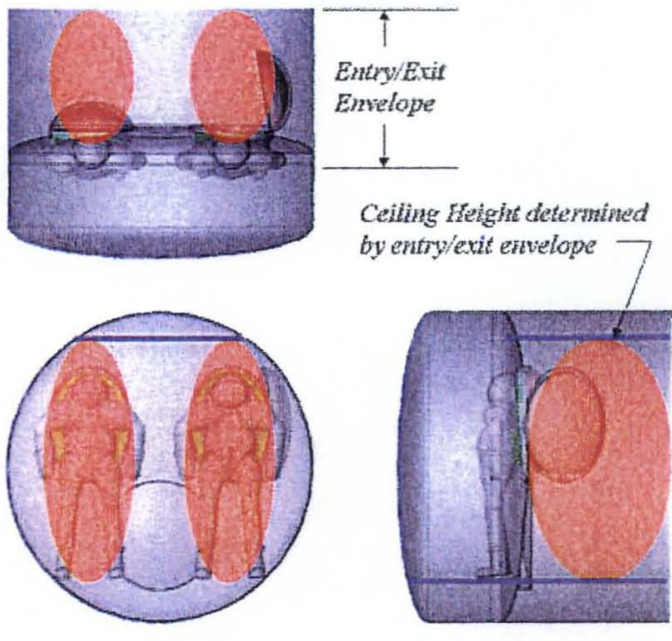

Full Diameter SL
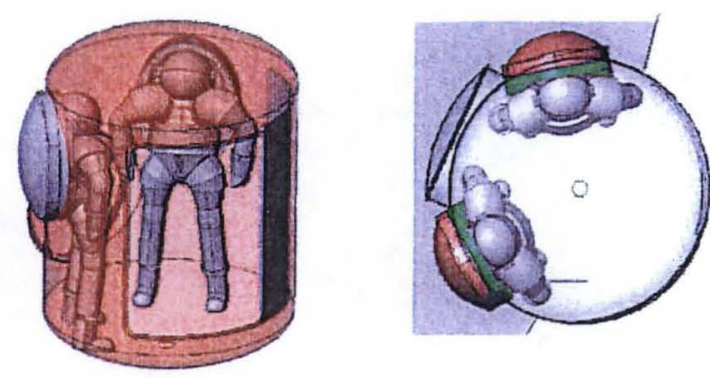

\section{Vertical Cylinder SL}

Figure 17 Two Types of SL Configurations

NASA's Ames Research Center (ARC) looked at both types of SLs as shown in Fig. 17. The full diameter concept uses the end-dome of a cylindrically shaped horizontal Habitat. With respect to volume, full end-dome concepts conform to

AL

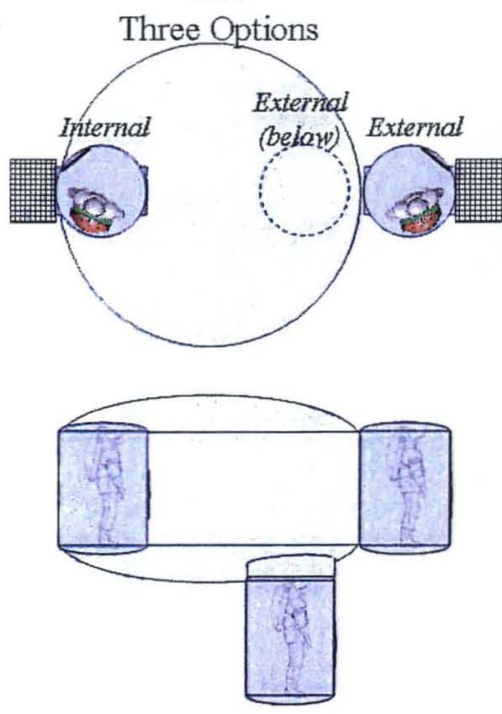

Figure $18 \mathrm{AL}$ and SL Locations for Vertical Cylinder Habitat
SL
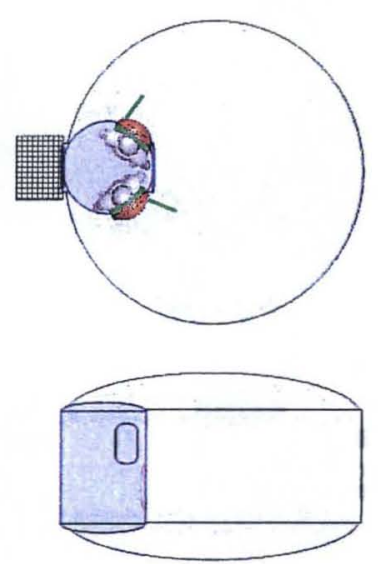

(1)

Habitat dimensions often resulting in oversized SLs that increase pump time and loss of air. The vertical cylinder configuration has the freedom to be optimized for SL functions, but requires shaping the Habitat structural enddome around the SL so that there is adequate interior volume for entering and exiting the suit.

\section{Lunar outpost} studies looked at larger diameter vertical

Habitats. Fig. 18 shows that there are 3 options for including the AL and only 1 for the SL. The diameter of the vertical Habitat extends to the dynamic envelope of the launch shroud. This means the SL is entirely within the pressurized volume. ALs 
can also be configured inside, but when manifested separately they can attach adjacent to or below the Habitat.

Summary

The AL is the favored concept. It is lighter, has fewer leak paths, is simpler to operate, offers a larger hatch for an incapacitated crew member, has greater commonality, and its larger hatchways, simplify crew and cargo translation (see Fig. 19). In addition, there are two other very important features that make the AL concept more attractive than the SL. These are: 1. the AL does not impose any design requirements on the suit or Habitat structure and 2. as a separate element, it is independent from the Habitat in procurement, fabrication, test, checkout, and flight manifesting.

\begin{tabular}{|c|c|c|}
\hline OBJECTIVE & FINDINGS & FAVORED \\
\hline $\begin{array}{l}\text { Minimize } \\
\text { resource loss }\end{array}$ & $\begin{array}{l}\text { Small volume best } \\
\text { Pump required } \\
\text { Pressure assisted hatches minimize leak } \\
\text { AL has minimum operable seal length }\end{array}$ & AL \\
\hline $\begin{array}{l}\text { Design for simple } \\
\text { operations }\end{array}$ & $\begin{array}{l}\text { AL } 1 \text { hatch vs. SL } 4 \text { hatches } \\
\text { AL eyes forward vs. Suitlock backing into PLSS dock } \\
\text { AL does not require rear-entry suit } \\
\text { Consolidated EVA support configuration } \\
\text { AL does not require equipment for different crew heights }\end{array}$ & AL \\
\hline Design for safety & $\begin{array}{l}\text { Two means of ingress/egress } \\
\text { AL (large hatch) better for incapacitated EVA crew member }\end{array}$ & AL \\
\hline $\begin{array}{l}\text { Seek } \\
\text { commonality }\end{array}$ & AL with 1 hatch vs. SL with 3 hatch types & AL \\
\hline $\begin{array}{l}\text { Minimize } \\
\text { program mass }\end{array}$ & $\begin{array}{l}\text { AL weighs less than SL } \\
\text { AL only on Habitat (none for lander and pressurized rover) }\end{array}$ & AL \\
\hline $\begin{array}{l}\text { Address lunar } \\
\text { dust }\end{array}$ & $\begin{array}{l}\text { AL and SL require IVA prep zone (dusty) } \\
\text { SL offers better routine dust control }\end{array}$ & SL \\
\hline Crew \& cargo & $\begin{array}{l}\text { Small AL \& SL volume means cycling pumps for cargo transfer } \\
\text { AL (large hatch) better for EVA handling }\end{array}$ & AL \\
\hline
\end{tabular}

Figure 19 Findings of $A L$ and SL Comparison

The AL does not possess the intrinsic dust control features of the SL, but there are questions regarding the effectiveness of the SL dust control. Due to extensive EVA in the lunar environment, suits are at greater risk of wear, damage and degraded performance. In order to verify EVA readiness, suits will require pre-EVA inspection on the "dusty" side of the SL. This means that the inspection process will expose the "clean" habitable area to the "dusty" airlock. Furthermore, with 4 crew members, EVAs will be scheduled using alternating pairs. Because suits are not interchangeable, the alternating crew will need to position their suits on the "dusty" side of the SL for the next EVA. This means the dusty suits are brought into the habitable area after every EVA just like the AL. 